\title{
SYNERGISTIC ACTIVITIES OF THE ESSENTIAL OILS HYPERICUM PERFORATUM WITH METHOTREXATE ON HUMAN BREAST CANCER CELL LINE MCF-7
}

\author{
GULAY GULBOL DURAN ${ }^{1}$, NIZAMI DURAN ${ }^{1}$, EMRAH AY $^{2}$, DURMUŞ ALPASLAN \\ KAYA $^{3}$, MADALINA GEORGIANA ALBU KAYA ${ }^{4}$ \\ ${ }^{1}$ Mustafa Kemal University, Medical Faculty, Microbiology \& Clinical Microbiology \\ Department, Hatay-Turkey, nizamduran@hotmail.com \\ ${ }^{2}$ Mustafa Kemal University, Medical Faculty, Medical Biology \& Genetics Department, Hatay- \\ Turkey,gulaygulbol@gmail.com \\ ${ }^{3}$ Mustafa Kemal University, Faculty of Agriculture, Field Crops Department, Hatay-Turkey, \\ dak1976@msn.com \\ ${ }^{4}$ INCDTP - Division Leather and Footwear Research Institute, 93 Ion Minulescu St., 031215, \\ Bucharest, Romania, albu_mada@yahoo.com
}

\begin{abstract}
Hypericum perforatum (Hypericaceae) is a perennial plant usually known as "Sarikantaron" that has been reported to have various important biological activities.In this present study, it was aimed to (I) identify the components (ii) show the synergistic activities of the essential oils Hypericum perforatum with methotrexate on human breast cancer cell line MCF-7. A normal [Madin-Darby Bovine Kidney (MDBK) cell line] and a cancer cell line [Human breast adenocarcinoma cell line (MCF-7)] were used in this study. The cell culture were treated with various concentrations of Hypericum perforatum's oils. The cytotoxic activity of the essential oils of Hypericum perforatum on the cell lines was measured using the MTT method and the results were evaluated as $\mathrm{IC}_{50}$. In this study, the presence of trans-caryophyllene, germacrene-D, $\alpha$-pinene, trans-cadina-1,4-diene, $\beta$ Selinene, caryophyllene oxide and $\alpha$-Selinene were identified as major constituents of Hypericum perforatum's oils. The essential oils of Hypericum perforatum also exhibited anticancer activities against MCF-7 cells. The $\mathrm{IC}_{50}$ values of the essential oils, MTX and the essentialoilsplus MTX weredetermined as $0.78,6.25$ and $0.195 \mathrm{~g} / \mathrm{ml}$, respectively, But, the essential oils of Hypericum perforatum was found to be non-cytotoxic for MDBK cells. In conclusion, the essential oils of Hypericum perforatum was chemically characterized and $\gamma$-muurolene, $\delta$-cadinene, germacrene B, $\alpha$-copaene, germacrene $\mathrm{D}$, bicyclogermacrene, and (E)-caryophyllene were found to be major constituents. The essential oils of Hypericum perforatum possess significant in vitro anticancer potential. The essential oils of Hypericum perforatum with MTX found to be significant effective against breast cancer cells. Further studies especially in vivo anticancer properties of Hypericum perforatum should be searched. These compounds found to be very promising compounds in the treatment of cancer therapy.
\end{abstract}

Keywords: MCF-7 cell line, anticancer, Hypericum perforatum, essential oil, synergistic activity.

\section{INTRODUCTION}

Breast cancer is one of the most common types of cancer in women. Also, it can be seen in both women and men. Breast cancer is the major cause of death among women (Siegel et al., 2014).

Cancer is one of the most important diseases of this of this century.Chemotherapy for the treatment of breast cancer is one of the most effective treatment options. Unfortunately, there is no effective drug for the treatment of certain cancers. There are common side effects of current drugs used in cancer treatment, as well as low efficiency in treatment. furthermore, drug resistance in cancer treatment is another serious problem (Raguz, 2008).

Therefore, the new drug researches for cancer chemotherapy continue. An important part of the studies on this topic has focused on natural products (Burmaoglu et al., 
Synergistic Activities of the Essential Oils Hypericum Perforatum with Methotrexate on Human Breast Cancer Cell Line MCF-7

2016). Because its many pharmacological features, Hypericum perforatum L. is interesting plant species for cancer research. Hypericum perforatum L. is a member of the Hypericaceae is reported to identify more than 400 species in the world (Mabberley, 1987). It can grow in many countries the world as well as in our country. H. perforatum is reported to have very important pharmacological properties among medicinal plants (Wills and Bone, 2000). Hypericum species reported to use in the folk medicine for the treatment of many diseases such as skin wounds, burns, eczema, gastrointestinal disorders and psychological disorders (Butterweck, 2003).

In this study, we aimed to investigate the anticancerogen activity of Hypericum perforatum on human breast adenocarcinoma (MCF-7) cell line. Also, it was aimed to search the synergistic activities of the essential oils Hypericum perforatum with MTX (Methotrexate) on MCF-7cells.

\section{MATERIALS AND METHODS}

\section{Isolation Of The Essential Oils}

Herba of Hypericum perforatum were collected from Amanos Mountain (Anatolian region) in blooming period and dried at room temperature. Essential oils were obtained from dried leaves and flowers. The aerial parts of Hypericum perforatum $(100 \mathrm{~g})$ were extracted by hydrodistillation with $1 \mathrm{~L}$ distilled water for $3 \mathrm{~h}$ using Neo-Clevenger apparatus. The oils were dried over anhydrous sodium sulfate and then stored in dark color glass bottles, at $-4{ }^{\circ} \mathrm{C}$ ready for GC-MS analysis.

\section{Analysis of GC/MS}

Analysis of the essential oils carried out by using Thermo Scientific Focus Gas Chromatograph equipped with MS, autosampler and TR-5MS (5\% Phenyl Polysilphenylenesiloxane, $0.25 \mathrm{~mm}$ x $30 \mathrm{~m}$ i.d, film thickness 0.25 ). The carrier gas was helium (99.9\%) at a flow rate of $1 \mathrm{~mL} / \mathrm{min}$; ionization energy was $70 \mathrm{eV}$. Mass range $\mathrm{m} / \mathrm{z}$ 50-650 amu. Data acquisition was scan mode. MS transfer line temperature was $250{ }^{\circ} \mathrm{C}$, MS Ionization source temperature was $220{ }^{\circ} \mathrm{C}$, the injection port temperature was $220^{\circ} \mathrm{C}$. The samples were injected with 250 split ratio. The injection volume was 1 L. Oven temperature was programmed in the range of 50 to $220^{\circ} \mathrm{C}$ at $3{ }^{\circ} \mathrm{C} / \mathrm{min}$. The structure of each compound was identified by comparison with their mass spectrum (Wiley 9 library). The data were handled using Xcalibur software program. The retention indices (RIs) were calculated for all volatile constituents using a homologous series of n-alkane standard solutions $\mathrm{C}_{8}-\mathrm{C}_{20}$ (Fluka, product no. 04070) and $\mathrm{C}_{21}-\mathrm{C}_{40}$ (Fluka, product no. 04071). 
ICAMS $2016-6^{\text {th }}$ International Conference on Advanced Materials and Systems

Table 1. Essential oil components of Hypericum perforatum

\begin{tabular}{ccccc}
\hline RT & RI & Compound Name & Cas \# & Area \% \\
\hline 2,36 & 902 & Nonane & $111-84-2$ & 1,28 \\
2,93 & 970 & Nonane, 3-methyl & $5911-04-6$ & 0,54 \\
3,68 & 1031 & $\alpha$-Pinene & $80-56-8$ & 10,59 \\
4,14 & 1060 & Decane, 2-methyl & $6975-98-0$ & 0,81 \\
4,94 & 1101 & Undecane & $1120-21-4$ & 0,52 \\
5,19 & 1114 & $\beta$-Pinene & $127-91-3$ & 0,64 \\
6,56 & 1172 & $\beta$-Myrcene & $123-35-3$ & 0,66 \\
9,15 & 1260 & cis-Ocimene & $6874-10-8$ & 1,16 \\
16,58 & 1465 & $\alpha$-Longipinene & $5989-08-2$ & 0,31 \\
17,20 & 1480 & $\alpha$-Ylangene & $14912-44-8$ & 0,3 \\
18,53 & 1514 & $\beta$-Bourbonene & $5208-59-3$ & 0,26 \\
20,41 & 1564 & $\beta$-Sesquiphellandrene & $20307-83-9$ & 1,36 \\
21,45 & 1590 & trans-Caryophyllene & $87-44-5$ & 17,13 \\
23,05 & 1634 & $\beta$-Chamigrene & $18431-82-8$ & 0,46 \\
23,19 & 1637 & Valencene & $4630-07-3$ & 0,25 \\
24,12 & 1662 & $\alpha$-Humulene & $6753-98-6$ & 1,05 \\
24,38 & 1669 & $\beta$-Farnesene & $18794-84-8$ & 2,69 \\
25,00 & 1685 & Junipene & $475-20-7$ & 0,21 \\
25,59 & 1700 & Germacrene-D & $23986-74-5$ & 11,22 \\
25,91 & 1709 & $\beta$-Selinene & $17066-67-0$ & 6,99 \\
26,05 & 1714 & trans-Cadina-1,4-diene & $87-44-5$ & 8,84 \\
26,12 & 1716 & $\alpha-S e l i n e n e$ & $473-13-2$ & 4,63 \\
26,49 & 1726 & Bicyclogermacrene & $100762-46-7$ & 1,36 \\
26,59 & 1729 & $\alpha$-Bergamotene & $17699-05-7$ & 0,98 \\
27,47 & 1754 & $\beta$-Elemene & $515-13-9$ & 2,53 \\
34,89 & 1969 & Caryophyllene oxide & $1139-30-6$ & 5,26 \\
37,26 & 2043 & Nerolidol & $7212-44-4$ & 1,06 \\
39,58 & 2126 & Spathulenol & $77171-55-2$ & 0,77 \\
39,84 & 2139 & 1-Dodecanol & $112-53-8$ & 3,93 \\
39,99 & 2146 & junipercamphor & NA & 0,31 \\
41,33 & 2206 & 1-Hexadecanol & $36653-82-4$ & 3,55 \\
41,91 & 2221 & Cubenol & $21284-22-0$ & 0,23 \\
42,10 & 2226 & $\alpha$-Bisabolol & $72691-24-8$ & 0,39 \\
42,42 & 2234 & Longipinane & NA & 0,56 \\
42,84 & 2245 & Veridiflorol & $552-02-3$ & 0,71 \\
43,39 & 2259 & Globulol & $51371-47-2$ & 1,6 \\
47,01 & 2370 & Junipene & $475-20-7$ & 0,38 \\
\hline & & &
\end{tabular}

\section{Determination of Non-Toxic DMSO Concentration}

To solve the plant essential oils, DMSO (dimethylsulfoxide) was used as a potent solvent. To determine the non-toxic concentration of DMSO on MDBK, $1 \times 10^{6}$ cells were inoculated into each well of flat bottomed plates. RPMI-1640 was selected as a growth medium. Plates were incubated 96 hours in the presence of decreasing amounts of DMSO $(8 \%, 4 \%, 2 \%, 1 \%, 0.5 \%)$.

To determine the non-cytotoxic concentration of Hypericum perforatum MadinDarby Bovine Kidney (MDBK) cell line was selected. The cells were cultured in RPMI 1640 supplemented with $10 \%$ fetal calf serum $1 \%(\mathrm{w} / \mathrm{v})$. Cells were incubated in a humidified atmosphere at $37^{\circ} \mathrm{C}$ in $5 \% \mathrm{CO}_{2}$. 


\section{Cytotoxic Tests}

For this purpose, the MTT assay was selected. MTT assay was performed as described previously (Mosmann, 1983). The normal and cancer cells were cultured in RPMI-1640 medium with $10 \%$ (w/v) fetal bovine serum. Incubation of the cells was performed at $37^{\circ} \mathrm{C}$ with $95 \%$ air and $5 \%$ carbon dioxide. The essential oils of the plants were dissolved in DMSO at the concentration of lower than $1 \%$. The culture cell is inoculated in 96-well plates overnight. After 96 hours of incubation with plants esssential oils, the cells were washed with PBS. And then, $100 \mathrm{~L}$ of $0.5 \mathrm{mg} / \mathrm{mL}$ MTT were added to all wells and incubated at $37^{\circ} \mathrm{C}$. The plate was incubated for 30 minutes at the same conditions. MTT reduction ratio was determined by measuring the difference in absorbance at 570 and $650 \mathrm{~nm}$ using a microplate reader. All tests were performed in triplicate.

\section{Statistical Analysis}

All data were obtained in the experiments repeated three times. Statistical analyses were performed using Student t-test. The $p$ value $<0.05$ was considered significant. All statistics in the present study were done using SPSS program.

\section{RESULTS AND DISCUSSION}

The chemical composition of the essential oils investigated in this study is shown in Table 1. Hypericum perforatum has been a rich constituents such as transCaryophyllene (17.13\%), Germacrene-D (\%11.22), $\alpha$-Pinene (10.59\%), trans-Cadina1,4-diene (8.84\%), $\beta$-Selinene (6.94\%), Caryophylleneoxide $(5.26 \%)$ and $\alpha$-Selinene (4.63\%), 1-Hexadecanol (3.93\%), $\beta$-Farnesene (2.69\%), $\beta$-Elemene $(2.53 \%)$, Nonane $(1.28 \%)$ and Nerolidol (1.06\%).

Trans-Caryophyllene (17.13\%), Germacrene-D (\%11.22), $\alpha$-Pinene (10.59\%), trans-Cadina-1,4-diene (8.84\%), $\beta$-Selinene $(6.94 \%)$, Caryophylleneoxide $(5.26 \%)$ and $\alpha$-Selinene $(4.63 \%)$ were identified as the major constituents in the essential oil of Hypericum perforatum. In studies conducted in previous years in the literature, caryophyllene, germacrene-D and $\alpha$-pinene have been reported that place among the important components of various medical plants. The activities of these components were investigated on some cancer cell lines (Amiel et al., 2007; Ofir et al., 2012; Quintans et al., 2013).

Today, there are a limited numbers and drug activity in cancer chemotherapy. Methotrexate is a commonly used drug for the treatment of many cancers types such as breast cancer (http://www.breastcancer.org). Due to the many side effects of MTX and the low treatment success, new active molecules investigation continues intensively. We have investigated the anticancer activity and the existence of a synergistic effect of Hypericum perforatum's oils with MTX in this study. 
ICAMS $2016-6^{\text {th }}$ International Conference on Advanced Materials and Systems

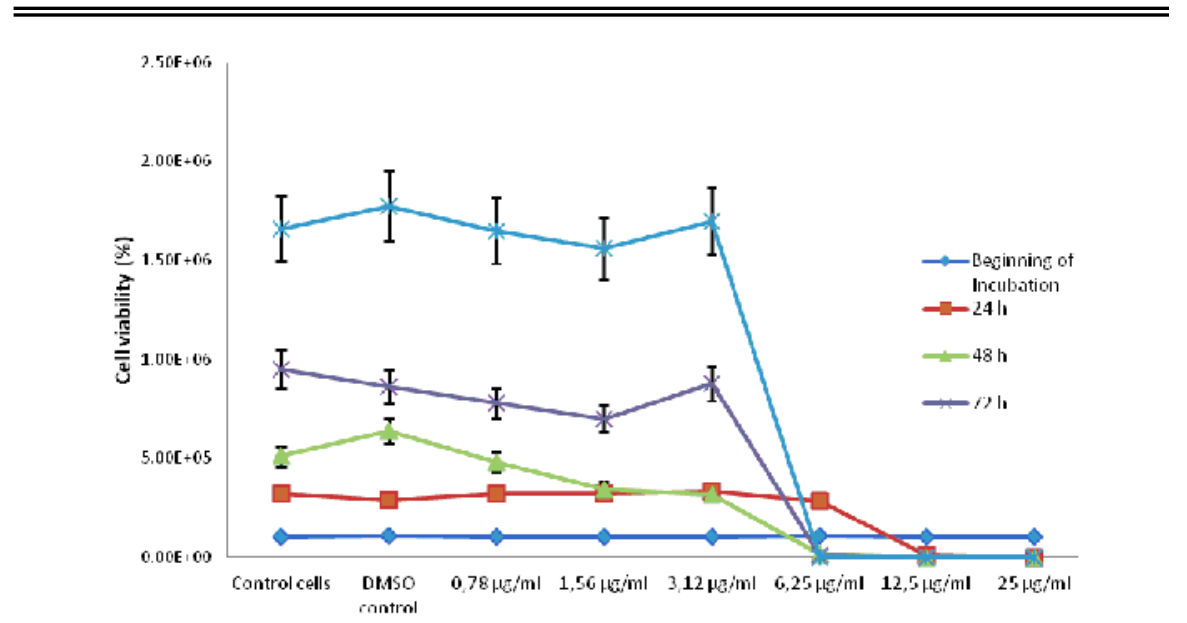

Figure 1. Effects of the essential oils of Hypericum perforatum on the proliferation of MCF-7 cells

The Inhibition concentrations of the essential oils of Hypericum perforatum against cancer (MCF-7) and normal cells (MDBK) cells were evaluated. The $\mathrm{IC}_{50}$ values were determined as $6.25 \mu \mathrm{g} / \mathrm{ml}$ and $25 \mu \mathrm{g} / \mathrm{ml}$, respectively. The $\mathrm{IC}_{50}$ value for MTX against MCF-7 cells was determined to be $0.78 \mu \mathrm{g} / \mathrm{ml}$. This value was calculated for the essential oils of Hypericum perforatum (EO of HP) plus MTX as $0.195 \mu \mathrm{g} / \mathrm{ml}$. It had been found that the essential oils of Hypericum perforatum enhanced synergistically the effect of MTX against MCF-7 cells (Figure 2).
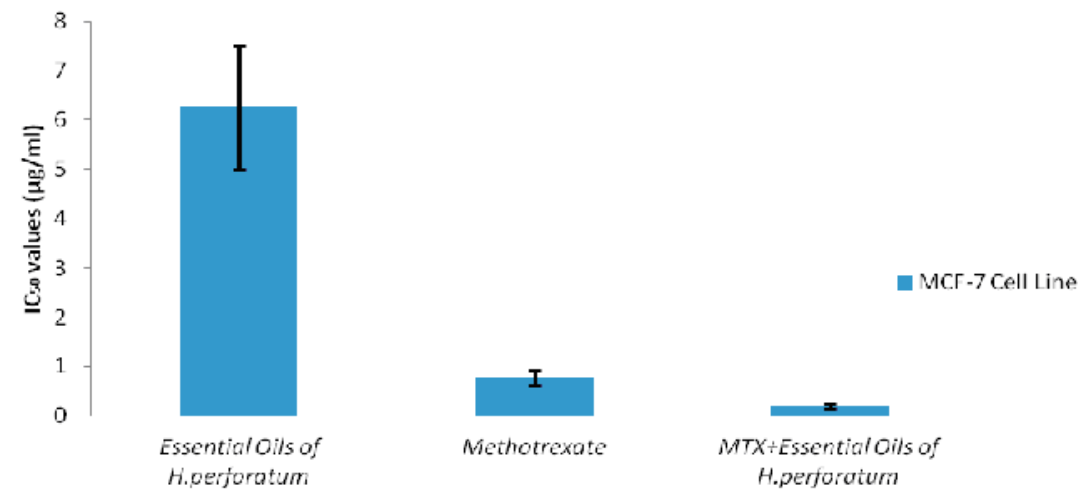

Figure 2. Effects of the essential oils of Hypericum perforatum on the proliferation of MCF-7 cells

In Figure 2, the synergistic effects of the methotrexate with the essential oils of Hypericum perforatum were investigated. As is clear in the figure 2, the essential oils of Hypericum perforatum significantly raised the effectiveness of the standard anticancerogen drug. A synergistic activity was determined between the essential oils of Hypericum perforatum and methotrexate. 


\section{CONCLUSIONS}

In conclusion, Hypericum perforatum collected from the South of Turkey (Hatay region) quite inhibited human lung adenocarcinoma cells, and was not toxic to normal cells. Besides this, the strong synergistic activity between methotraxate and Hypericum perforatum was determined. We think that Hypericum perforatum L. may be a promising natural product for the breast cancer chemotherapy. However, further studies are needed on this issue.

\section{REFERENCES}

Amiel, E., Legault, J. and Pichette, A. (2007), "Potentiating effect of beta-caryophyllene on anticancer activity of alpha-humulene, isocaryophyllene and paclitaxel", Journal of Pharmacy and Pharmacology, 59, 16437.

Burmaoglu, S., Algul, O., Anıl, D.A. et al. (2016), "Synthesis and anti-proliferative activity of fluorosubstituted chalcones", Bioorganic \& Medicinal Chemistry Letters, 26, 3172-6.

Butterweck, V. (2003), "Mechanism of action of St. John'sWort in depression. What is known?", CNS Drugs, 17, 539-62.

Mabberley, D.J. (1987), The Plant Book, Cambridge University Press, Cambridge.

Mosmann, T. (1983), "Rapid colorimetric assay for cellular growth and survival application to proliferation and cytotoxicity assays", Journal of Immunological Methods, 65, 55-63.

Ofir, R., Dudai, N. and Soloway, E. (2012), " $\beta$-Caryophyllene, a Compound Isolated from the Biblical Balm of Gilead (Commiphora gileadensis), Is a Selective Apoptosis Inducer for Tumor Cell Lines", EvidenceBased Complementary and Alternative Medicine, Article ID 872394-12.

Quintans, J.S., Soares, B.M., Ferraz, R.P. et al. (2013), "Chemical constituents and anticancer effects of the essential oil from leaves of Xylopialaevigata", Planta Medica, 79, 123-30.

Raguz, S. and Yague, E. (2008), "Resistance to chemotherapy: New treatments and novel insights into an old problem", British Journal of Cancer, 99, 387-91.

Siegel, R., Ma, J., Zou, Z., et al. (2014), "Cancer Statistics, 2014”, CA: A Cancer Journal for Clinicians, 64, 9-29.

Wills, R.B.H., Bone, K. and Morgan, M. (2000), "Herbal products: active constituents, models of action and quality control", Nutritional Research Reviews, 13, 47-77.

*** http://www.breastcancer.org/treatment/druglist/methotrexate. 